\title{
Development of an ELISA using the recombinant protein CP1957 of Corynebacterium pseudotuberculosis for diagnosis of caseous lymphadenitis in sheep
}

\author{
Carlos Guilherme Rosa Reis ${ }^{1}$, Henrique Ramos Angelo ${ }^{1 *}$, Andréa de Fátima Silva Rezende ${ }^{1}$, \\ Alexandre Antunes Brum', Vasco Ariston de Carvalho Azevedo², Sibele Borsuk ${ }^{1}$
}

From 5th Congress of the Brazilian Biotechnology Society (SBBIOTEC)

Florianópolis, Brazil. 10-14 November 2013

\section{Background}

Caseous lymphadenitis (CLA) is a disease caused by the bacteria Corynebacterium pseudotuberculosis which affects small ruminants such as sheeps and goats, leading to severe economic losses. The development of more sensitive and specific diagnoses showing effectiveness on asymptomatic animals is essential for disease's control. This study purposes the use of the recombinant protein CP1957 of C. pseudotuberculosis in indirect ELISA using sheep sera.

\section{Methods}

The amplification of the $c p 1002$ 1957 gene was performed using the primers F5' CGCGGATCCGGGCCTCGCGACTGG 3' and R5' CCGGAATTCTTACCAGGCGTTCATAACGT 3'. The cp1002_1957 gene was cloned in the BamHI e EcoRI sites of the pAE vector. The recombinant clones (pAE/1957) were characterized enzymatically and by DNA sequencing. E. coli BL21 Star cells were transformed with the pAE/1957 vector for the expression of rCP1957 protein, the induction was performed by the addition of IPTG $1 \mathrm{mM}$ to the culture media. The purification was realized by affinity chromatography on a Sepharose column loaded with nickel. The purity was determined using a $12 \%$ SDS-PAGE, and the concentration determined by a BCA kit. For indirect ELISA, the purified rCP1957 was utilized as antigen in a concentration of $1 \mu \mathrm{g} / \mathrm{mL}$. The sheep sera and the anti-sheep conjugated

\footnotetext{
${ }^{1}$ Research Laboratory for Infectious Diseases, Center of Technological Development, Biotechnology, Universidade Federal de Pelotas, Pelotas, RS, Brazil

Full list of author information is available at the end of the article
}

with peroxidase were used in 1:100 and 1:5000 dilutions, respectively. A total of 49 sheep sera were analyzed, where 14 were from asymptomatic animals and 35 were from negative animals. The sensitivity and specificity of ELISA-r1957 were analyzed on receiver operating characteristic (ROC).

\section{Results and conclusion}

The statistical analysis of the ELISA-rCP1957 results presented sensitivity and specificity values of $92.9 \%$ e $85.7 \%$, respectively, when the absorbance cutoff value of 0.063 was used. Thus, we can conclude that the developed ELISA, using the recombinant protein CP1957 can be used for the CLA diagnoses with good levels of sensitivity and specificity.

\section{Acknowledgements \\ Foundation for Research Support of the State of Rio Grande do Sul (FAPERGS), through project No. 11/1894-0, and CNPq}

\section{Authors' details}

${ }^{1}$ Research Laboratory for Infectious Diseases, Center of Technological Development, Biotechnology, Universidade Federal de Pelotas, Pelotas, RS, Brazil. 'Laboratory of Cellular and Molecular Genetics, Department of General Biology, Universidade Federal de Minas Gerais, Belo Horizonte, MG, Brazil.

Published: 1 October 2014

\section{References}

1. Dorella FA, Pacheco LG, Meyer R, Portela RW, Miyoshi A, Azevedo V: A description of genes of Corynebacteriumpseudotuberculosisuseful in diagnostics and vaccine applications. Genet Mol Res 2008, 7(1):252-260

2. Dercksen DP, Brinkhof JM, Dekker-Nooren T, Maanen K, Bode CF, Baird G, Kamp EM: A comparison of four serological tests for the diagnosis of caseous lymphadenitis in sheep and goats. Vet Microbiol 2000, 75(2):167-175. 
3. Guimarães Ade S, Dorneles EM, Andrade Gl, Lage AP, Miyoshi A, Azevedo V, Gouveia AM, Heinemann MB: Molecular characterization of Corynebacterium pseudotuberculosis isolates using ERIC-PCR. Vet Microbiol 2011, 153(3-4):299-306

4. Huerta B, Gómez-Gascón L, Vela Al, Fernandez-Garayzabal JF, Casamayor C, Maldonado A: Comparison of two biochemical methods for identifying Corynebacteriumpseudotuberculosis isolated from sheep and goats. Vet $J$ 2013, 196(3):552-554

5. Santos AR, Carneiro A, Gala-García A, Pinto A, Barh D, Barbosa E, Aburjaile F, Dorella F, Rocha F, Guimaraes L, Zurita-Turk M, Ramos R, Almeida S, Soares S, Pereira U, Abreu VC, Silva A, Miyoshi A, Azevedo V: The Corynebacterium pseudotuberculosis in silico predicted pan-exoproteome. BMC Genomics 2012, 13(Suppl 5):S6.

doi:10.1186/1753-6561-8-S4-P163

Cite this article as: Rosa Reis et al: Development of an ELISA using the recombinant protein CP1957 of Corynebacterium pseudotuberculosis for diagnosis of caseous lymphadenitis in sheep. BMC Proceedings 2014 8(Suppl 4):P163.

\section{Submit your next manuscript to BioMed Central} and take full advantage of:

- Convenient online submission

- Thorough peer review

- No space constraints or color figure charges

- Immediate publication on acceptance

- Inclusion in PubMed, CAS, Scopus and Google Scholar

- Research which is freely available for redistribution

Submit your manuscript at www.biomedcentral.com/submit 